\title{
Comparison of the effect of two support materials on copper removal from aqueous solution in the activated sludge process
}

\author{
S. R. M. Kutty, E. H. Ezechi, S. G. Khaw, C. L. Lai \& M. H. Isa \\ Department of Civil Engineering, Universiti Teknologi PETRONAS, \\ Malaysia
}

\begin{abstract}
Two support materials, microwave incinerated rice husk ash (MIRHA) and groundwater treatment plant sludge (GWTPS), were used as support materials for biomass in the removal of copper from aqueous solution during a continuous flow study. A third reactor containing biomass alone without the addition of support material (RB) was used as a control to monitor the performance of the support materials. All reactors were given 15 days for the acclimatization of biomass. The reactors containing MIRHA and GWTPS were given an additional 10 days for acclimation after the addition of the support materials on day 15. All reactors were identically designed with a size of $8.5 \mathrm{~L}$ and operated at a flowrate of $7 \mathrm{~L} / \mathrm{d}$ and SRT of 30 days across 8 different phases. Different concentrations of $\mathrm{Cu}(\mathrm{II})$ ranging from $0.5 \mathrm{mg} / \mathrm{L}$ to $15 \mathrm{mg} / \mathrm{L}$ were applied to the reactors at different phases. Results obtained from each phase of the experiments showed that GWTPS and MIRHA improved copper toxicity resistance in their respective reactors. For the control reactor (RB), copper toxicity was significant and violated the DOE Malaysia copper effluent standard at phase 5 (influent concentration $2 \mathrm{mg} / \mathrm{L}$ ) whereas MIRHA and GWTPS reactors violated the DOE Malaysia copper effluent standard at phase 7 (influent concentration $10 \mathrm{mg} / \mathrm{L}$ ) respectively. However, GWTPS containing reactor showed slightly better support for toxicity resistance than reactor MIRHA. The toxicity of copper on the three reactors was observed in the reduction of mixed liquor volatile suspended solids (MLVSS) within each reactor. For the control, MLVSS rapidly decreased from phase 3 to phase 8 whereas MIRHA and GWTPS reactors increased from phase 3 to phase 6 and decreased from phase 7 to phase 8 . These results have shown that MIRHA and GWTPS have the potential of improving biomass resistance to toxicity of heavy metals.
\end{abstract}

Keywords: copper, activated sludge, toxicity, rice husk. 


\section{Introduction}

The generation of wastewater containing hazardous pollutants from various industrial activities has become a subject of concern. Industrial wastewaters can cause severe environmental problems when disposed into lakes, rivers and waterbodies at concentrations higher than the specified guideline. Industrial activities such as electroplating, metal finishing, tanning, mining, metallurgy and chemical manufacturing produce wastewater containing heavy metals during operations [1]. Heavy metals such as copper are commonly present in such wastewaters and are harmful when discharged at high concentration [2]. Discharge of heavy metals from industrial wastewaters into water bodies can result in increased concentration of heavy metals in soil when such water sources are used for irrigation. Heavy metals in soil can readily form complexes with other compounds such as boron and increase their potential toxicity [3, 4]. Excessive discharge of copper to the environment can lead to adverse health effects such as anemia, liver, kidney damage, stomach and intestinal irritation [5].

The rise in urbanization and industrialization has increased the demand for water. Sustainability of existing water bodies to provide sufficient water has become an issue of concern. As a result, more water sources are being investigated and identified as potential alternatives to supplement limited fresh water resources especially in arid areas [6, 7]. Industrial and other wastewater sources could be potential supplement for fresh water resources when they are properly treated. It is therefore necessary to utilize efficient and cost effective treatment methods for the treatment of contaminated wastewater.

Common techniques utilized in the removal of copper from wastewater include ion exchange, ultra-filtration, chemical precipitation, reverse osmosis, flocculation, adsorption and electrolysis. However, some of these techniques present significant demerits such as high operation cost, regeneration of resin, loss of adsorbent material, membrane fouling and high sludge production which hinder their optimal use $[1,8,9]$. Due to the risk and dangers associated with high copper concentrations in water bodies, various government authorities have stringently regulated the discharge of copper into water bodies. The copper discharge limits set by the United States Environmental Protection Agency (EPA) is $0.0049 \mathrm{mg} / \mathrm{L}$, whereas Malaysia Department of Environment (DOE) Environmental Quality Act (1974) set the copper discharge limit as $0.2 \mathrm{mg} / \mathrm{L}$ (Standard A) [10].

Biological methods of wastewater treatment have been efficient for the removal of different pollutants from wastewater. However, water contaminated with heavy at high concentration can be toxic to microbial population within the reactor. The use of support materials in biological treatment processes is gaining wide attention because it improves the resistance of biomass to toxicity. Powdered activated carbon has been successfully utilized to augment activated sludge process for the treatment of semi-aerobic landfill leachate [11].

The objective of this paper is to examine the effect of two support materials derived from rice husk and groundwater sludge respectively and utilized to 
improve biomass resistance to copper toxicity. Efficiency of the support materials were evaluated across different copper concentrations and compared with a control reactor.

\section{Methodology}

\subsection{Wastewater preparation}

The wastewater used in this study was synthetically prepared. An appropriate quantity of grinded Purina Alpo High Protein Puppy Dog Meal was dissolved in distilled water to yield concentrations simulating medium strength domestic wastewater. Synthetic wastewater was used in order to provide more consistent organic loadings. $0.15 \mathrm{~mL} / \mathrm{L}$ of phosphate buffer (phosphate buffer used for the BOD dilution water) was added to improve nutrient concentration in the wastewater. The $\mathrm{C}: \mathrm{N}: \mathrm{P}$ ratio of the prepared synthetic wastewater was calculated to be 100:24:3, meeting the required minimum 100:5:1 ratio for domestic wastewater.

\subsection{Reactor configuration}

Three reactors made of acrylic glass were used in this study. The total volume of each reactor is $8.5 \mathrm{~L}$. The first reactor containing biomass alone was used as control reactor. In the second reactor, biomass and microwave incinerated rice husk ash (MIRHA) was combined. In the second reactor, biomass and groundwater treatment plant sludge (GWTPS) were combined. The reactors were equipped with adequate air diffusers to provide sufficient oxygen to the biomass for degradation of organic materials.

\subsection{Preparation of support materials}

Rice husk was collected and washed severally with distilled water to remove impurities. It was subsequently dried at $105^{\circ} \mathrm{C}$ for 2 hours until constant weight was attained. It was then subjected to Microwave Incinerator at $800^{\circ} \mathrm{C}$ for 2 hours. The Microwave Incinerated Rice Husk Ash (MIRHA) produced was used in this study. The adsorbent was then stored in a tight container before use.

GWTPS was collected from Air Kelantan Sdn. Bhd. groundwater treatment plant in muddy sludge form. GWTPS was dried at $105^{\circ} \mathrm{C}$ for 24 hours according to Standard Methods for the Examination of Water and Wastewater. It was then grinded into powder form and stored in a closed container.

\subsection{Reactor operations}

The reactors were operated using biomass from the aeration tank of an activated sludge treatment plant. The flowrate of the reactors were $7 \mathrm{~L} / \mathrm{d}$. All reactors were operated at extended aeration (solid retention time (SRT) $\approx 30$ days, design mixed liquor suspended solids (MLSS) $\approx 4000 \mathrm{mg} / \mathrm{L}$ ), in order to promote the growth of slow growing bacteria such as Nitrosomonas and Nitrobacter. Slow growing 
bacteria are important for the removal of nitrogen from wastewater. Copper was dosed in the form of Copper Sulfate $\left(\mathrm{CuSO}_{4}\right)$ solution. The study was conducted in 8 different phases comprising of different copper doses as shown below in Table 1.

Table 1: Copper dosage and reactor operation.

\begin{tabular}{|l|l|l|}
\hline Phase & Activity & Period (day) \\
\hline 1 & Acclimation & $1-15$ \\
\hline 2 & $\begin{array}{l}\text { MIRHA and GWTPS } \\
\text { addition }\end{array}$ & $16-25$ \\
\hline 3 & Copper dosage $0.5 \mathrm{mg} / \mathrm{L}$ & $26-33$ \\
\hline 4 & Copper dosage $1 \mathrm{mg} / \mathrm{L}$ & $34-45$ \\
\hline 5 & Copper dosage $2 \mathrm{mg} / \mathrm{L}$ & $46-57$ \\
\hline 6 & Copper dosage $5 \mathrm{mg} / \mathrm{L}$ & $58-63$ \\
\hline 7 & Copper dosage $10 \mathrm{mg} / \mathrm{L}$ & $64-72$ \\
\hline 8 & Copper dosage $15 \mathrm{mg} / \mathrm{L}$ & $73-76$ \\
\hline
\end{tabular}

Acclimation period of 15 days were given on all reactors to stabilize the biomass. On day 16, $2000 \mathrm{mg} / \mathrm{L}$ of MIRHA and GWTPS adsorbent was added to their reactors respectively. An additional acclimatization period of 10 days were given to the reactors to enable the biomass adapt to MIRHA and GWTPS without causing any shock effect. The sludge age was controlled through daily sludge recycling and wasting during phase 1 and 2. However, from Phase 3 onwards, biomass was only recycled without wasting to ensure maximum growth of biomass to cushion for copper toxicity. The concentration of MIRHA and GWTPS in the mixed liquor was maintained at $2000 \mathrm{mg} / \mathrm{L}$ throughout Phase 2, by adding MIRHA and GWTPS to the aeration tank daily, taking into consideration the MIRHA and GWTPS wasted daily in the waste sludge and discharged into the effluent (from effluent Total Suspended Solids measurement). From Phase 3 onward, $100 \mathrm{mg} / \mathrm{L}$ MIRHA and GWTPS was added daily into the aeration tank. This is to prevent MIRHA and GWTPS adsorbent from reaching the exhaustion point, where all the adsorbent becomes saturated with adsorbate. The influent and effluent samples were collected daily and the performance of both reactors was monitored for 76 days continuously.

\subsection{Testing procedure}

Copper test was carried out according to US Environmental Protection Agency (USEPA) Bicinchoninate method for powder pillows (Method 8506). Mixed liquour suspended solids (MLSS), and mixed liquor volatile suspended solids (MLVSS) were analyzed according to standard methods for the examination of water and wastewater. Total Chemical Oxygen Demand (TCOD) was analyzed through Hach method using DR 2800 spectrophotometer. Biochemical oxygen demand $\left(\mathrm{BOD}_{5}\right)$ was determined by standard method number 5210 . 


\section{Results and discussion}

Figure 1 represents the influent copper concentration at 8 different phases investigated in this study. Phase 1 and 2 were considered as acclimatization phases. Influent wastewater containing copper was applied to the reactors from phase 3.

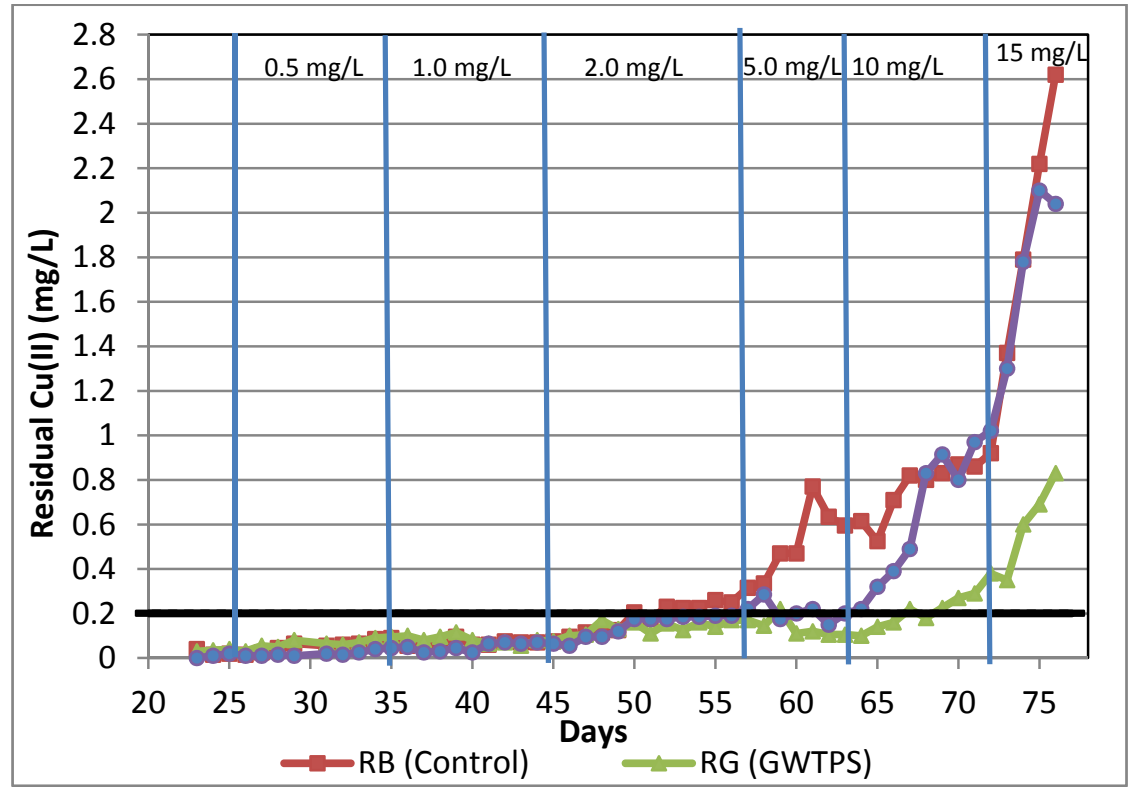

Figure 1: Copper removal for different phases.

\subsection{Copper removal by control reactor}

Figure 1 shows copper removal in the control reactor. After acclimatization periods of phases 1 and 2, influent wastewater containing copper concentration of $0.5 \mathrm{mg} / \mathrm{L}$ was applied to the control reactor from phase 3 . Copper was significantly removed and residual copper concentration was $0.065 \mathrm{mg} / \mathrm{L}$. During phase 4, copper concentration applied to the control reactor was increased to $1.0 \mathrm{mg} / \mathrm{L}$. Significant copper removal was observed in this phase having residual copper concentration of $0.075 \mathrm{mg} / \mathrm{L}$. Increasing copper concentration to $1.0 \mathrm{mg} / \mathrm{L}$ in this phase did not have any significant toxic effect on the activities of the biomass. Influent copper concentration was increased to $2.0 \mathrm{mg} / \mathrm{L}$ in phase 5 . Effective copper removal was observed in the initial stage. However, copper removal gradually decreased as time proceeds and eventually became stable. Residual copper concentration was about $0.315 \mathrm{mg} / \mathrm{L}$, above the regulatory discharge limit guideline of $0.2 \mathrm{mg} / \mathrm{L}$. Further investigation was done in phase 6 with copper concentration increased to $5.0 \mathrm{mg} / \mathrm{L}$. However, copper toxicity was significant in this phase. Copper removal rapidly decreased from the initial stage of this phase 
and maintained such trend until the end. Residual copper concentration was 0.595 $\mathrm{mg} / \mathrm{L}$. In phases 7 and 8 , copper concentration in the influent wastewater were increased to $10 \mathrm{mg} / \mathrm{L}$ and $15 \mathrm{mg} / \mathrm{L}$ respectively. Copper removal did not improve in both phases. Copper removal decreased in phase 7 and phase 8. However, copper removal was more affected in phase 8. Residual copper concentration in phases 7 and 8 were $0.9 \mathrm{mg} / \mathrm{L}$ and $2.6 \mathrm{mg} / \mathrm{L}$ respectively.

Between phases 3-4, copper removal was below the regulatory discharge limit of $0.2 \mathrm{mg} / \mathrm{L}$ but violated the standard from phase 5-8 due to negative and toxic impact of copper to the microbial population. Similar observation was made by Marques et al. [12] in their study with zinc contaminated wastewater. This was corroborated by the downward trend of mixed liquor volatile suspended solids (MLVSS) from phase 4 to phase 8. The poor performance of the microorganisms from phase 4-8 could be attributed to high concentration of copper. Similar observation was made by Malakahmad et al. [13] in their study of $\mathrm{Hg}^{2+}$ and $\mathrm{Cd}^{2+}$ removal from synthetic petrochemical wastewater using sequencing batch reactors (SBR). The metals impacted negatively on the microbial population at high concentration. The control reactor can meet the regulatory discharge limit of 0.2 $\mathrm{mg} / \mathrm{L}$ when initial copper concentration is below $2 \mathrm{mg} / \mathrm{L}$.

\subsubsection{Copper removal by MIRHA reactor}

MIRHA was added to the reactor in phase 2. MIRHA was allowed to acclimate with the biomass in the reactor in phase 2. Phases 1 and 2 were therefore considered as acclimatization period. In phase 3 , copper concentration of $0.5 \mathrm{mg} / \mathrm{L}$ was applied to the reactor. Copper removal in the reactor was significant in phase 3. Residual copper concentration obtained in this phase was $0.025 \mathrm{mg} / \mathrm{L}$ and no toxicity or shock effect was observed. In phase 4, copper concentration in influent wastewater was increased to $1.0 \mathrm{mg} / \mathrm{L}$. Copper removal in this phase maintained a stable state and residual concentration slightly increased to about $0.06 \mathrm{mg} / \mathrm{L}$ towards the end of the phase. No significant increase was observed in the effluent sample and no toxic or shock effect was observed throughout the phase. In phase 5, copper concentration in influent wastewater was increased to $2.0 \mathrm{mg} / \mathrm{L}$. Copper removal in this phase slightly reduced with residual concentration about $0.2 \mathrm{mg} / \mathrm{L}$. Slight toxicity and shock effect on the microbial population was observed as shown by the reduction of copper removal efficiency and MLVSS. This observation has been made by other works during the removal of $\mathrm{Hg}^{2+}$ and $\mathrm{Cd}^{2+}$ from synthetic petrochemical wastewater using sequencing batch reactors (SBR) [13]. However, it could be said that MIRHA influenced the resistance of the biomass towards copper toxicity. In phase 6 , copper concentration in the influent wastewater was increased to $5 \mathrm{mg} / \mathrm{L}$. The increase in copper concentration had a complex effect on the reactor in this phase. In the initial stage, a toxic effect was observed but the reactor stabilized towards the end of the phase. The residual copper concentration was about $0.2 \mathrm{mg} / \mathrm{L}$ in the final stage. The stability of the reactor towards the end of this phase could be attributed to the influence of MIRHA and the resistance of toxicity and shock effect by the biomass. In phases 7 and 8, copper concentration were increased to $10 \mathrm{mg} / \mathrm{L}$ and $15 \mathrm{mg} / \mathrm{L}$ respectively. Copper removal decreased in both phases. Copper removal 
was slow and the removal efficiency of copper decreased in both phases. However, this effect was more significant in phase 8 . The decrease of copper removal efficiency in both phases could be attributed to severe toxicity and shock effect at high metal concentrations. Residual copper concentrations in phases 7 and 8 were $0.97 \mathrm{mg} / \mathrm{L}$ and $2.04 \mathrm{mg} / \mathrm{L}$ respectively. Although, MIRHA could improve the resistance of toxicity on biomass, the metals can be toxic on MIRHA at high concentration when the optimum concentration threshold is surpassed thereby resulting to a relative decrease of biomass stimulation effect. Further increase of the heavy metal concentration will have an adverse effect on the cell growth, until the complete reduction of the microbial activity and the failure of the system [14]. Addition of MIRHA to the reactor improved copper removal within the regulatory guideline limit up to phase 6 but the violated the standard limit from phases 7-8. Similar observations were observed by Marques et al., on the performance of an aerobic granular sequencing batch reactor fed with zinc contaminated wastewater.

\subsubsection{Copper removal by GWTPS reactor}

GWTPS was added to the reactor in phase 2 and allowed to acclimate with the biomass in the reactor. Phases 1 and 2 were therefore considered as acclimation period. In phase, copper concentration of $0.5 \mathrm{mg} / \mathrm{L}$ was applied to the reactor. Copper removal was significant in this phase with residual copper concentration of $0.07 \mathrm{mg} / \mathrm{L}$. No shock effect or toxicity was noticed in this phase. In phase, influent copper concentration was increased to $1.0 \mathrm{mg} / \mathrm{L}$ and significant copper removal was achieved with residual copper concentration of $0.075 \mathrm{mg} / \mathrm{L}$. No shock or toxic effect was observed. In phase 5 , influent copper concentration was increased to $2.0 \mathrm{mg} / \mathrm{L}$. A slight decrease in copper removal was observed in the initial stage but stabilized thereafter. Residual copper concentration obtained was $0.17 \mathrm{mg} / \mathrm{L}$. Copper toxicity and shock effect at this stage was not very significant on the microbial population. GWTPS provided adequate support to cushion for toxicity and shock effect within this phase. In phase 6, influent copper concentration was increased to $5.0 \mathrm{mg} / \mathrm{L}$. Copper removal was significant in this phase. GWTPS provided support for the biomass to resist copper toxicity and shock effect in this phase. Residual copper concentration was $0.105 \mathrm{mg} / \mathrm{L}$. In phase 7, influent copper concentration was increased to $10 \mathrm{mg} / \mathrm{L}$. Shock effect and toxicity slightly affected the microbial population in this phase. GWTPS provided support for biomass to resist toxicity from the initial stage to half way of the phase. However, the biomass reached its exhaustion point towards the end of the phase and copper toxicity was observed. Residual copper concentration reached 0.29 $\mathrm{mg} / \mathrm{L}$. In phase 8 , influent copper concentration was increased to $15 \mathrm{mg} / \mathrm{L}$. Residual copper concentration slightly increased and reached $0.76 \mathrm{mg} / \mathrm{L}$ due to copper toxicity and shock effect on the microbial population.

GWTPS showed significant acclimation with the biomass and high copper toxicity resistance on the reactor throughout the study. The copper concentration threshold of inhibitory effect on microorganisms is $1.0 \mathrm{mg} / \mathrm{L}$ [15]. However, increasing copper concentration did not show any significant negative effect on GWTPS reactor due to improved biosorption, bioaccumation and bioreduction processes [16]. In phases 7 and 8 , residual concentration slightly violated the 
regulatory guideline limit of $0.2 \mathrm{mg} / \mathrm{L}$ due to damage on the surfaces of living cells, resulting in the partial loss of sorption abilities and the release of accumulated metal into the solution [16]. Copper can significantly damage the surfaces of living cells which could lead to partial loss of cell binding abilities and release of accumulated copper back into solution [17]. Similar observations was also made by other works [16].

\subsection{Biomass resistance and copper toxicity on the reactors}

Biomass resistance to copper toxicity on all reactors was examined through the increase and decrease of MLVSS in each reactor. The start-up MLSS in the reactor was about $4000 \mathrm{mg} / \mathrm{L}$.

In the control reactor, the start-up MLVSS was about $2400 \mathrm{mg} / \mathrm{L}$. Copper toxicity was significant from phase 3 until phase 4 . Between phase 4 and 5 , reactor MLVSS stabilized. However, reactor MLVSS decreased from phase 6-8. Copper toxicity was more significantly observed in the control reactor. The final MLVSS concentration in the reactor at phase 8 was less than $1000 \mathrm{mg} / \mathrm{L}$. This implies that substrate utilization at high concentration could have resulted to loss of microbial activities within the reactor as shown in Figure 2.

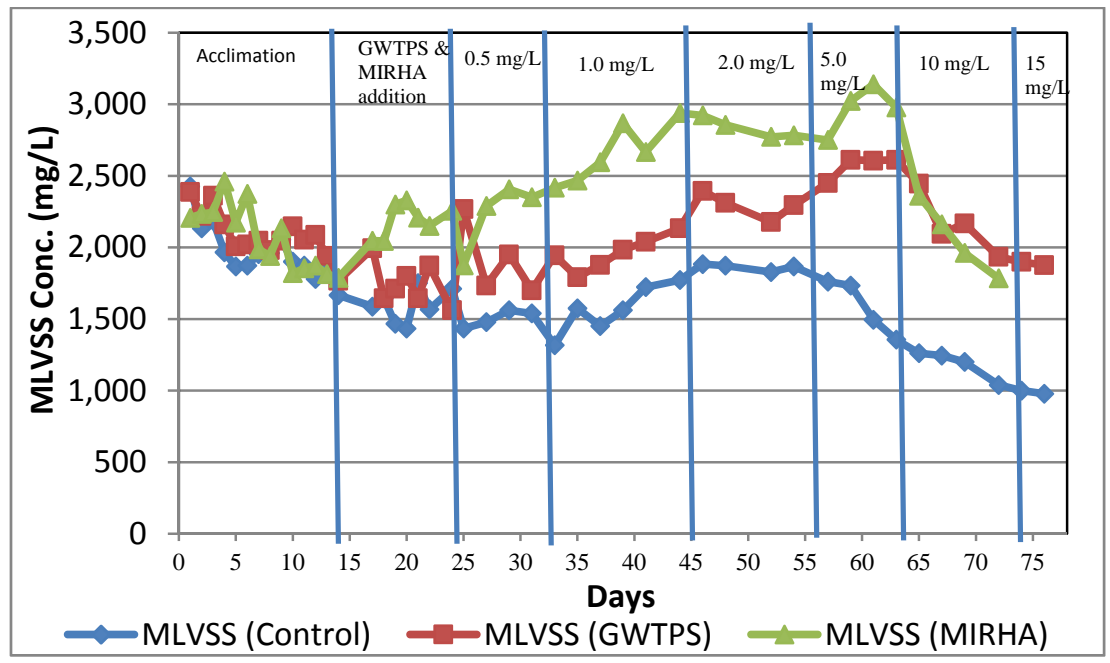

Figure 2: MLVSS concentration in all reactors (mg/L).

In MIRHA reactor, initial MLVSS concentration was about $2206 \mathrm{mg} / \mathrm{L}$ as shown in Figure 2. MIRHA enabled the biomass to withstand shock effect and copper toxicity. After the initial shock effect on the biomass in phase 3 (day 26), the reactor stabilized and copper toxicity was resisted from phase 3-6. Significant growth of micro-organisms was also observed within phase 3-6. However, from phase 7-8, copper toxicity on the biomass was significant and the MLVSS decreased. The final MLVSS in the reactor was about $1783 \mathrm{mg} / \mathrm{L}$ in phase 8 . The 
resistance of toxicity by the biomass in this reactor could be attributed to the influence of MIRHA on the biomass.

In GWTPS reactor, initial MLVSS concentration was about $2386 \mathrm{mg} / \mathrm{L}$ as shown in Figure 2. Copper toxicity was observed in phase 3. The zig-zag pattern of the plot in this stage indicates a resistance to toxicity by the biomass. From phase 4-6, the plot shows a successful resistance of toxicity by the biomass and subsequent growth of the microbial population. However, from phase 7-8, the biomass reached its exhaustion point and MLVSS decreased. The resistance of biomass to copper toxicity in this reactor could be attributed to the impact of GWTPS during the operation. The final MLVSS concentration in the reactor was about $1876 \mathrm{mg} / \mathrm{L}$.

Addition of heavy metals in all reactors caused the decrease of MLVSS in the initial stage but stabilized thereafter. Similar observation was made by Khor et al. [16]. The MLSS concentration decreased in the initial stage when $5 \mathrm{mg} / \mathrm{L} \mathrm{NI(II)}$ and $\operatorname{Cr}(\mathrm{III})$ was added to the reactor but showed significant improvement afterwards.

\section{Conclusion}

The efficiency of two support materials to improve biomass resistance to copper toxicity was investigated. MIRHA and GWTPS are two support materials utilized in this study and are commonly considered as waste. A third reactor was set up to examine the effect of the support materials on the activated sludge treatment process. Both support materials were found to be effective and influenced biomass resistance to copper toxicity. Copper toxicity was significantly observed in the control reactor. Whereas copper toxicity was significantly observed in phase 7 for MIRHA and GWTPS reactors, copper toxicity was observed in phase 5 for the control reactor. However, GWTPS reactor showed significant copper toxicity resistance than MIRHA reactor. Whereas the residual copper concentration for GWTPS reactor in phase 7 and 8 were $0.29 \mathrm{mg} / \mathrm{L}$ and $0.83 \mathrm{mg} / \mathrm{L}$, the residual copper concentration for MIRHA reactor in phase 7 and 8 were $0.97 \mathrm{mg} / \mathrm{L}$ and $2.04 \mathrm{mg} / \mathrm{L}$ respectively. The two support materials were effective and provided resistance for the consortium of biomass within the reactor. More studies should focus on the elemental composition of GWTPS.

\section{Acknowledgement}

The authors would like to thank Universiti Teknologi PETRONAS (UTP) for its support towards this project.

\section{References}

[1] S. Lu and S. W. Gibb, "Copper removal from wastewater using spent-grain as biosorbent,” Bioresource Technology, vol. 99, pp. 1509-1517, 2008. 
[2] F. Akbal and S. Camcl, "Copper, chromium and nickel removal from metal plating wastewater by electrocoagulation,” Desalination, vol. 269, pp. 214-222, 2011.

[3] E. H. Ezechi, M. H. Isa, and S. R. B. M. Kutty, "Boron in Produced Water: Challenges and Improvements: A Comprehensive Review,” Journal of Applied Sciences, vol. 12, 2012.

[4] E. H. Ezechi, M. H. Isa, S. R. M. Kutty, and A. Yaqub, "Boron removal from produced water using electrocoagulation," Process Safety and Environmental Protection, 2014.

http://dx.doi.org/10.1016/j.psep.2014.08.003

[5] E. Kiliç. Heavy Metals Pollution in Water. Cag Kimya Turkey. Available at: http://www.tip2000.com/

[6] C. Escobar, C. Soto-Salazar, and M. Ines Toral, "Optimization of the electrocoagulation process for the removal of copper, lead and cadmium in natural waters and simulated wastewater," Journal of Environmental Management, vol. 81, pp. 384-391, 2006.

[7] E. H. Ezechi, M. H. Isa, and Shamsul Rahman Mohamed Kutty, "Removal of Boron from Produced Water by Electrocoagulation," in 10th WSEAS International Conference on Environment, Ecosystems and Development (EED'12), Switzerland, pp. 87-92, 2012.

[8] Q. Yang and N. Kocherginsky, “Copper removal from ammoniacal wastewater through a hollow fiber supported liquid membrane system: modeling and experimental verification,” Journal of Membrane Science, vol. 297, pp. 121-129, 2007.

[9] N. C. Feitoza, T. D. Gonçalves, J. J. Mesquita, J. S. Menegucci, M.-K. Santos, J. A. Chaker, et al., "Fabrication of glycine-functionalized maghemite nanoparticles for magnetic removal of copper from wastewater,” Journal of Hazardous Materials, vol. 264, pp. 153-160, 2014.

[10] S. Kutty, E. Ezechi, S. Khaw, C. Lai, and M. Isa, "Evaluation of copper removal using MIRHA as an adsorbent in a continuous flow activated sludge system,” Water Pollution XII, vol. 182, p. 233, 2014.

[11] N. Aghamohammadi, H. b. A. Aziz, M. H. Isa, and A. A. Zinatizadeh, "Powdered activated carbon augmented activated sludge process for treatment of semi-aerobic landfill leachate using response surface methodology,” Bioresource Technology, vol. 98, pp. 3570-3578, 2007.

[12] A. P. Marques, A. F. Duque, V. S. Bessa, R. B. Mesquita, A. O. Rangel, and P. M. Castro, "Performance of an aerobic granular sequencing batch reactor fed with wastewaters contaminated with $\mathrm{Zn}^{2+}$," Journal of Environmental Management, vol. 128, pp. 877-882, 2013.

[13] A. Malakahmad, A. Hasani, M. Eisakhani, and M. H. Isa, "Sequencing Batch Reactor (SBR) for the removal of $\mathrm{Hg}^{2+}$ and $\mathrm{Cd}^{2+}$ from synthetic petrochemical factory wastewater," Journal of Hazardous Materials, vol. 191, pp. 118-125, 2011.

[14] P. Gikas and P. Romanos, "Effects of tri-valent (Cr (III)) and hexa-valent (Cr (VI) chromium on the growth of activated sludge," Journal of Hazardous Materials, vol. 133, pp. 212-217, 2006. 
[15] M. A. Eddy, Wastewater Engineering Treatment and Reuse, Fourth ed.: McGraw-Hill, New York, USA, 2004.

[16] S. Khor, S. Ng, P. Lim, and C. Seng, "The effects of nickel (II) and chromium (VI) on oxygen demand, nitrogen and metal removal in a sequencing batch reactor,” Environmental Technology, vol. 32, pp. 19031914, 2011.

[17] J. Kaduková and E. Virčíková, “Comparison of differences between copper bioaccumulation and biosorption,” Environment International, vol. 31, pp. 227-232, 2005. 